\title{
Chagas disease in Italy: breaking an epidemiological silence
}

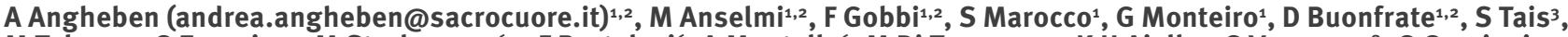

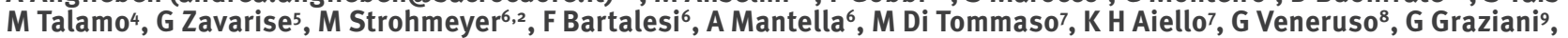

M M Ferrarii10, I Spreafico ${ }^{10}$, E Bonifacio ${ }^{11}$, G Gaiera $^{12}$, M Lanzafame ${ }^{13}$, M Mascarello ${ }^{13}$, G Cancrini ${ }^{14}$, P Albajar-Viñas ${ }^{15}$, Z Bisoffi ${ }^{1,2}$, A Bartoloni ${ }^{6,2}$

1. Centre for Tropical Diseases, Sacro Cuore - Don Calabria Hospital, Negrar, Italy

2. COHEMI project (COordinating resources to assess and improve HEalth status of MIgrants from Latin America)

3. Service of Epidemiology and Laboratory for Tropical Diseases, Sacro Cuore - Don Calabria Hospital, Negrar, Italy

4. Infectious Disease Unit, G. Rummo Hospital, Benevento, Italy

5. Paediatric Division, Sacro Cuore - Don Calabria Hospital, Negrar, Italy

6. Infectious and Tropical Diseases Unit, Careggi University Hospital, Florence, Italy

7. Obstetric and Gynaecologic Department, Careggi University Hospital, Florence, Italy

8. Infectious Diseases Unit, Anna Meyer Children's University Hospital, Florence, Italy

9. Immunohaematology and Transfusion Unit, Careggi University Hospital, Florence, Italy

10. Obstetrics and Gynaecology Clinic, L. Mangiagalli Hospital, Milan, Italy

11. Obstetrics and Gynaecology Division, Sacro Cuore - Don Calabria Hospital, Negrar, Italy

12. Infectious Diseases Division, San Raffaele Hospital, Milan, Italy

13. Infectious Diseases Division, G.B. Rossi University Hospital, Verona, Italy

14. Public Health Sciences Department, La Sapienza University, Rome, Italy

15. WHO Programme on Control of Chagas disease, Department of Control of Neglected Tropical Diseases, World Health Organization, Geneva, Switzerland

Citation style for this article:

Angheben A, Anselmi M, Gobbi F, Marocco S, Monteiro G, Buonfrate D, Tais S, Talamo M, Zavarise G, Strohmeyer M, Bartalesi F, Mantella A, Di Tommaso M, Aiello KH, Veneruso G, Graziani G, Ferrari MM, Spreafico I, Bonifacio E, Gaiera G, Lanzafame M, Mascarello M, Cancrini G, Albajar-Viñas P, Bisoffi Z, Bartoloni A. Chagas disease in Italy: breaking an epidemiological silence.

Euro Surveill. 2011;16(37):pii=19969. Available online: http://www.eurosurveillance.org/ViewArticle.aspx?Articleld=19969

Article published on 15 September 2011

Chagas disease, a neglected tropical disease that due to population movements is no longer limited to Latin America, threatens a wide spectrum of people (travellers, migrants, blood or organ recipients, newborns, adoptees) also in non-endemic countries where it is generally underdiagnosed. In Italy, the available epidemiological data about Chagas disease have been very limited up to now, although the country is second in Europe only to Spain in the number of residents from Latin American. Among 867 at-risk subjects screened between 1998 and 2010, the Centre for Tropical Diseases in Negrar (Verona) and the Infectious and Tropical Diseases Unit, University of Florence found $4.2 \%$ patients with positive serology for Chagas disease ( $83.4 \%$ of them migrants, $13.8 \%$ adoptees). No cases of Chagas disease were identified in blood donors or HIV-positive patients of Latin American origin. Among 214 Latin American pregnant women, three were infected (resulting in abortion in one case). In 2005 a case of acute Chagas disease was recorded in an Italian traveller. Based on our observations, we believe that a wider assessment of the epidemiological situation is urgently required in our country and public health measures preventing transmission and improving access to diagnosis and treatment should be implemented.

\section{Introduction}

Chagas disease is a protozoan zoonosis caused by Trypanosoma cruzi, with a widespread distribution from the south of the United States to Mexico and Central and South America. In endemic countries it is responsible for the highest estimated burden of neglected tropical diseases, affecting 8 to 10 million people [1]. As a consequence of migration flows, the disease has been recorded also in non-endemic countries and is becoming a global health problem [2]. In Europe, about 59,000-108,000 cases of Chagas disease are estimated [3] . Italy has a large number of Latin American resident migrants, second in Europe only to Spain, as a result of various migratory waves to Argentina, Brazil, Chile, Uruguay and Venezuela through the last 200 years, until the direction of migration reversed in the 1970 [3].

The majority of Latin American migrants reached Italy in the past ten years, with a growing trend [4] . Migrants from different countries tend to have a patchy distribution in Italian Regions, with a major concentration in the north and in Rome. For instance most Bolivians live in Bergamo Province, Lombardy, Ecuadorians in Liguria Region and Peruvians in big cities such as Milan, Florence and Rome [4].

This new epidemiological scenario prompted the Centre for Tropical Diseases in Negrar (CTDN) and the Infectious and Tropical Diseases Unit, University of Florence, Florence (ITDUF) to join to better define the epidemiological situation and to promote prevention and control programmes focused on Chagas disease 
and other neglected diseases. In this paper we present the first data obtained by the two Centres in their daily clinical practice and screening programmes targeted to at-risk population in Italy.

These findings should throw light on a disease so far unnoticed in our country. We tried to follow the recent indications by the European network representatives of Non-Endemic Countries Initiative on data collection, risk assessment and control of blood tranfusions, appropriate and sustainable detection strategies for at-risk populations (children, women of child-bearing age, immunodeficient patients), and access to diagnosis and treatment [5].

\section{Methods}

Prevalence estimation of Trypanosoma cruzi infection and Chagas disease in Latin American migrants living in Italy

The expected number of $T$. cruzi-infected Latin American migrants living in Italy was calculated using the estimated total number of migrants from endemic countries and the average $T$. cruzi infection rate in the country of birth according to either Schmunis et al. [2] or the Panamerican Health Organization (PAHO) [6]. For their estimations, Schmunis et al. used seroprevalences of Chagas disease in Latin American countries in 1990. Their values are generally higher than the PAHO data, which refer to the year 2005, when the situation had improved thanks to disease control initiatives in Latin America.

The source for the number of Latin American legal migrants in Italy on 1 January 2008 was the Italian National Statistics Institute [7]. Data on undocumented migrants were obtained from the Report on Immigration published by Caritas/Migrantes [4] and from the Regional Agencies of Migration. Literature data were also used [3] .

Regarding the estimation of progression from indeterminate to chronic cardiac Chagas disease, a conservative rate of $20 \%$ was used [2].

\section{Diagnosis and screening programmes}

The two Centres systematically offered Chagas disease testing to all patients with epidemiological risk (such as migration, adoption from or travel to endemic countries, or being born to a Latin American mother), who attended their services for any reason in the study period. The period considered was April 1998 to April 2010 for CTDN and January 2007 to December 2009 for ITDUF.

The first part of the study consisted of a retrospective review of the patient files, in an anonymous way. The second part concerned screening of pregnant women, blood donors and human immunodeficiency virus (HIV)-positive subjects of Latin American origin or born to a Latin American mother. Patients' consent was obtained before testing.
Migrants, travellers and expatriates

Migrants from and travellers to endemic countries, regardless of the duration of travel, were considered eligible when returning from Central and South American countries, excluding the Caribbean where Chagas disease is not endemic. Children born to Latin American mothers were also included. Expatriates were defined as individuals resident in Chagas disease-endemic countries for occupational purposes.

\section{Adopted children}

Adopted children were studied as part of a collaboration of CTDN and ITDUF with services for health promotion of adopted children at the Paediatric Division of Sacro Cuore Hospital, Negrar and Anna Meyer Children's University Hospital, Florence, respectively. Adoptees' access to care differs from that of other immigrants in Italy in that there are specialised centres that offer testing for diseases present in the country of birth.

\section{Pregnant women}

In 2008, CTDN and ITDUF implemented a screening programme targeted to Latin American pregnant women at Sacro Cuore Hospital, Negrar, and Careggi University Hospital, Florence, in collaboration with the respective Maternal and Child Health Departments. In 2009 the screening included also pregnant women attending the Obstetrics and Gynaecology Clinic at L. Mangiagalli Hospital in Milan. Women were offered to be tested during a prenatal visit, or latest during pre-partum.

\section{Blood donors}

All but one donor included in the study were enrolled at the Immunohaematology and Transfusion Unit, Careggi University Hospital, Florence, which began screening donors for Chagas disease in 2008. Only migrants from endemic areas or children born to Latin American mothers were screened.

\section{HIV/AIDS}

From January 2008 to April 2010, HIV-positive Latin American migrants attending or referred to ITDUF, the Infectious Disease Division of the University Hospital of Verona and the Infectious Diseases Division at San Raffaele Hospital, Milan were offered to be serologically tested for antibodies against $T$. cruzi. The three centres are important reference centres for the management and treatment of HIV-positive patients.

\section{Laboratory methods}

Serology for T. cruzi was performed using a combination of two tests: an immunochromatographic assay (Chagas Quick Test, Cypress Diagnostics, Belgium) and an ELISA based on recombinant antigens (BioELISA Chagas, Biokit S.A., Spain) or T. cruzi lysate, (DRG CHAGAS IgG, Germany). In some cases serum samples were tested by two ELISAs. In case of discordant result, a third assay was performed, as recommended by the World Health Organization (WHO) [8]. In case of infants born to $T$. cruzi-infected women, serological evaluation 
was performed at birth, at one and eight months of age. At each evaluation, blood samples were submitted to parasitological testing (microscopic examination of microhaematocrit) and nested or real-time PCR with primers $\mathrm{TCZ}_{1} / \mathrm{TCZ}_{2}$ and $\mathrm{TCZ}_{3} / \mathrm{TCZ}_{4}$ ) [9] and serological evaluation. Molecular diagnosis was performed at the Laboratory of Parasitology, Faculty of Pharmacy, at the University of Barcelona, Spain or at the Public Health Sciences Department at La Sapienza University in Rome, Italy. Infants were considered infected in case of microscopic detection of T. cruzi or PCR positivity or seropositivity at eight months of age.

\section{Results}

Estimated Trypanosoma cruzi infection

rate and Chagas disease in Latin

American migrants living in Italy

The results are summarised in Table 1. At the end of 2007, around 400,000 Latin American migrants were estimated to be resident in Italy, the most represented countries being Brazil, Ecuador and Peru. According to the seroprevalence of Chagas disease in the country of origin reported by Schmunis et al.[2] or PAHO [6], $11,217-12,578$ or $5,902-6,572$ T. cruzi-infected migrants were expected to live in Italy at the beginning of 2008. In the most pessimistic scenario of progression to the cardiac form, up to 2,516 individuals were estimated to be affected by chronic cardiac Chagas disease in the same period.
Patients attending the two centres

Overall, 867 individuals attending CTDN and ITDUF were tested. The mean age of the population was 26.2 years (range: 1-85 years). A slight predominance of males (51.4\%) was observed. Countries of origin and categories of the patients are shown in Table 2. In 1.2\% of cases, classification was not possible for missing information.

Overall, 36 of 867 patients ( $4.2 \%$ ) had a positive result of $T$. cruzi serology. The largest part of the seropositive individuals were migrants $(83.4 \%)$, followed by adopted children (13.8\%). One was a short-term Italian traveller to Brazil (Santa Catarina). None of 100 expatriates were positive and none of the six newborns from seropositive mothers had a positive test eight months after birth.

\section{Migrants}

In the study period, 266 migrants were tested, 147 of whom (65\%) were women. The mean age of this population was 34 years (range: $4-83$ years). The distribution of nationalities is shown in Table 3. Among the 30 migrants infected by T. cruzi, 23 were from Bolivia, two from Argentina, two from Paraguay, one from Brazil, one from Ecuador, and one from Mexico.

\section{Expatriates}

None of the 100 tested expatriates was seropositive for T. cruzi. In the retrospective analysis, it was not possible to know the host country/ies for a considerable

TABLE 1

Estimated Trypanosoma cruzi infection rate and cardiac chronic Chagas disease in Latin American migrants Italy, on 1 January 2008

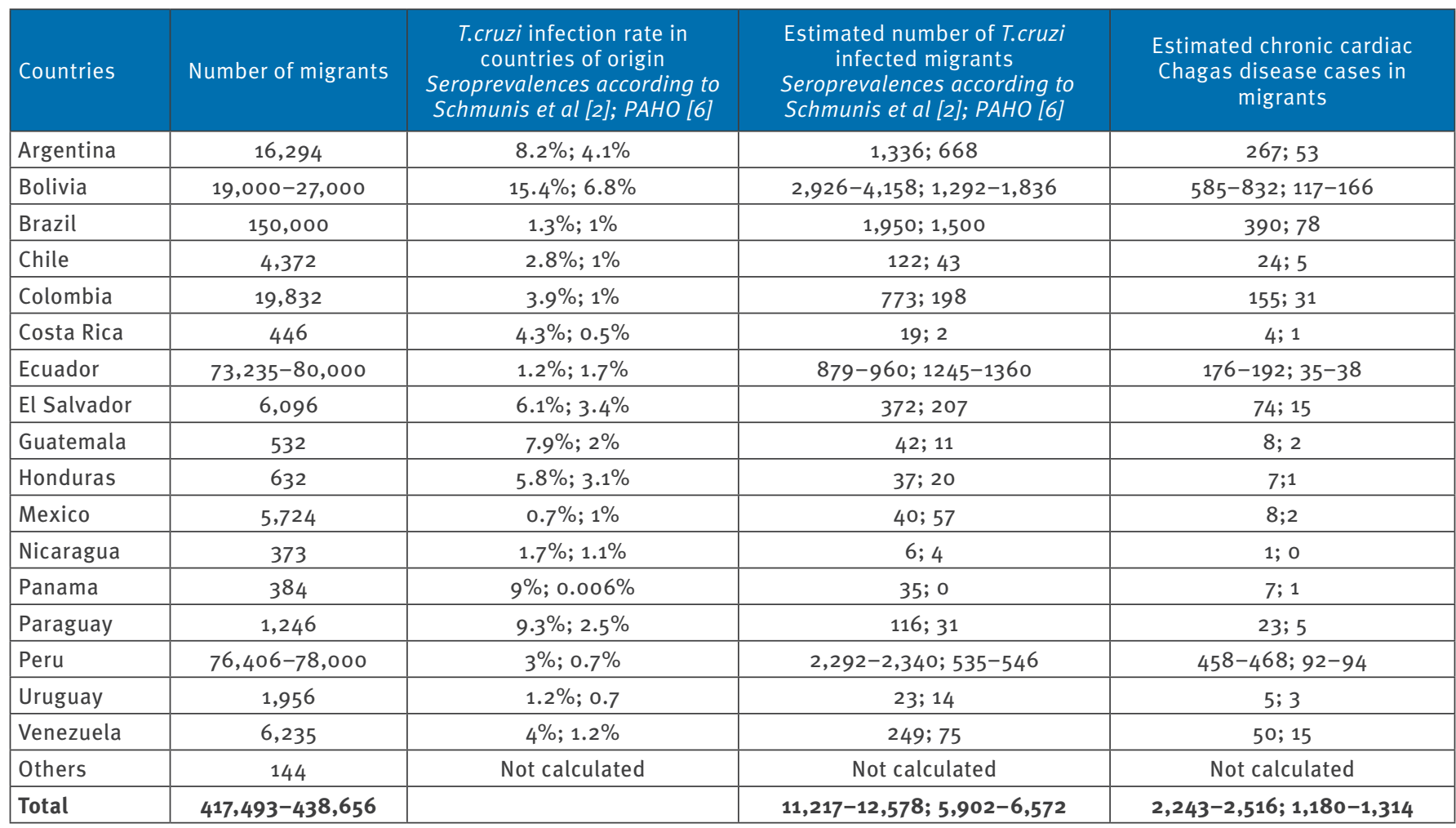


proportion of subjects in this group (72\%) from whom the data collection forms reported only 'residence in Chagas disease endemic countries'. Details of the country were available for 28 patients, Brazil and Bolivia being the most represented countries with 11 and 4 individuals, respectively (Table 3 ). The mean age was 46.9 years (range: $2-85$ years). Males were represented with $58 \%$.

\section{Travellers}

During the study period, only 28 travellers were screened (six in Florence and 22 in Negrar) with one positive result. This case was a patient with acute Chagas disease returning from a short journey (less than one week) to Santa Catarina, Brazil during the 2005 food-borne outbreak (caused by sugar-cane juice) of Chagas disease in that region. (personal communication, Francesca Prati, 2005). He confirmed having consumed crude sugar-cane juice. The patient was

\section{TABLE 2}

Seroprevalence of Trypanosoma cruzi antibodies in the study participants , by country of origin and category, April 1998-April $2010(\mathrm{n}=876)$

\begin{tabular}{|c|c|c|}
\hline & $\begin{array}{c}\text { Number of } \\
\text { individuals } \\
\mathrm{n}(\% \text { of all } 867)\end{array}$ & $\begin{array}{c}\text { Seropositive } \\
\text { patients: } \\
\text { n (\% of } 36 \\
\text { seropositive } \\
\text { patients) }\end{array}$ \\
\hline \multicolumn{3}{|l|}{ Country of origin } \\
\hline Argentina & $17(2)$ & $2(5.5)$ \\
\hline Bolivia & $157(18)$ & $28(77.7)$ \\
\hline Brazil & $255(29.4)$ & $1(2.8)$ \\
\hline Chile & $35(4)$ & $\mathrm{o}(\mathrm{o})$ \\
\hline Colombia & $120(13.8)$ & o (o) \\
\hline Costa Rica & $10(1.2)$ & $0(0)$ \\
\hline Ecuador & $17(2)$ & $1(2.8)$ \\
\hline Guatemala & $5(0.6)$ & $\mathrm{o}(\mathrm{o})$ \\
\hline Italy & $11(1.3)$ & $1(2.8)$ \\
\hline Mexico & $16(1.9)$ & $1(2.8)$ \\
\hline Nicaragua & $1(0.1)$ & $\mathrm{o}(\mathrm{o})$ \\
\hline Paraguay & $3(0.4)$ & $1(2.8)$ \\
\hline Peru & $91(10.4)$ & o (o) \\
\hline Uruguay & $1(0.1)$ & o (o) \\
\hline Venezuela & $12(1.4)$ & o (o) \\
\hline Unknown b & $116(13.4)$ & $1(2.8)$ \\
\hline \multicolumn{3}{|l|}{ Classification } \\
\hline Migrants & $266(30.7)$ & $30(83.4)$ \\
\hline Adoptees & $457(52.7)$ & $5(13.8)$ \\
\hline Expatriates & $100(11.5)$ & $\mathrm{o}(\mathrm{o})$ \\
\hline Travellers & $28(3.2)$ & $1(2.8)$ \\
\hline Born to seropositive mother & $6(0.7)$ & o (o) \\
\hline Unknown & $10(1.2)$ & o (o) \\
\hline
\end{tabular}

a Individuals evaluated between April 1998 and April 2010 at the Centre for Tropical Diseases, Negrar and between January 2007 and December 2009 at the Infectious and Tropical Diseases Unit, Florence.

b Patients originating from or having visited an unspecified Chagas disease-endemic area. successfully treated (to our knowledge). We do not have more detailed clinical information for this case.

\section{Adopted children}

Overall, 457 adopted children were tested, corresponding to $52.7 \%$ of the study population (mean age: 7.1 years; range: 2 months -33 years). Five children, all adopted from Bolivia, were found to be seropositive for $T$. cruzi (mean age: 5 years, range: 4-6 years). This corresponded to $7 \%$ of all Bolivian adopted children included in the study $(n=71)$.

Screening programmes for pregnant women, blood donors and HIV-positive subjects

Pregnant women

A total of 214 pregnant women (mean age: 32 years, range: 14-44 years) were screened. The countries of origin are reported in Table 4 . Three women (1.4\%) had a positive result, two from Bolivia and one from Paraguay. One aborted spontaneously in the 16th week (the cause has not been investigated). The other two cases did not transmit the infection. Anti-trypanosomal treatment was offered to all infected women after breastfeeding. The $T$. cruzi infection rate among the subgroup of women of Bolivian origin was $29 \%$ (two of seven).

\section{Blood donors}

A total of 28 specimens were obtained from subjects at risk for $T$. cruzi infection. Half of them were men with a mean age of 39 years (range: 21-55 years). The countries of origin for donors are reported in Table 4. All tested donors had negative results for T. cruzi infection.

\section{TABLE 3}

Nationalities (or country of residence for expatriates) of study participants ${ }^{\text {, }}$, April 1998-April $2010(\mathrm{n}=825)$

\begin{tabular}{|l|c|c|c|c|c|c|}
\hline Country & $\begin{array}{c}\text { Migrants } \\
(\mathrm{n}=266)\end{array}$ & $\%$ & $\begin{array}{c}\text { Adoptees } \\
(\mathrm{n}=457)\end{array}$ & $\%$ & $\begin{array}{c}\text { Expatriates } \\
(\mathrm{n}=100)\end{array}$ & $\%$ \\
\hline Argentina & 14 & 5.3 & 1 & 0.2 & 2 & 2 \\
\hline Bolivia & 75 & 28.2 & 71 & 15.5 & 4 & 4 \\
\hline Brazil & 80 & 30 & 157 & 34.4 & 11 & 11 \\
\hline Chile & 1 & 0.4 & 34 & 7.4 & 0 & 0 \\
\hline Colombia & 22 & 9.7 & 98 & 21.4 & 0 & 0 \\
\hline Costa Rica & 1 & 0.4 & 9 & 2 & 0 & 0 \\
\hline Ecuador & 8 & 3.5 & 6 & 1.3 & 3 & 3 \\
\hline Guatemala & 0 & 0 & 3 & 0.7 & 1 & 1 \\
\hline Mexico & 10 & 3.8 & 4 & 0.9 & 1 & 1 \\
\hline Nicaragua & 0 & 0 & 0 & 0 & 1 & 1 \\
\hline Paraguay & 3 & 1.3 & 0 & 0 & 0 & 0 \\
\hline Peru & 26 & 9.8 & 65 & 14.2 & 0 & 0 \\
\hline Uruguay & 1 & 0.4 & 0 & 0 & 0 & 0 \\
\hline Venezuela & 5 & 2.2 & 1 & 0.2 & 5 & 5 \\
\hline Unknown & 21 & 7.9 & 8 & 1.8 & 72 & 72 \\
\hline
\end{tabular}

Individuals evaluated between April 1998 and April 2010 at the Centre for Tropical Diseases, Negrar and between January 2007 and December 2009 at the Infectious and Tropical Diseases Unit, Florence. Travellers, infants born from seropositive mothers and not classified subjects are not represented. 


\section{HIV/AIDS}

Seventy HIV-positive Latin American migrants were screened, of whom $78 \%$ were men with a mean age of 38 years (range: $22-56$ years). Their countries of origin are reported in Table 4. Patients from Brazil and Peru, countries with a low prevalence of Chagas disease, represented more than a half of the sample. None of the patients had an indeterminate or positive test $T$. cruzi infection. In the group of HIV-positive migrants studied at ITDUF $(n=43), 14$ had in their clinical history a nadir of a CD4+ T lymphocyte count below $200 / \mu \mathrm{l}$.

\section{Discussion}

\section{Epidemiology of Chagas disease in Italy}

In the past decade, Chagas disease has been increasingly reported in non-endemic countries as a result of improved case finding and growing migration flows. Moreover, the lack of effective control measures and preparedness in most European countries facilitated the emergence of congenital or transfusion-related cases [3].

In Europe, Spain and Italy are the most popular destinations for Latin American migrants. Officially, 275,671 Latin Americans were resident in Italy on 1 January, 2008 [7], most from Peru, Ecuador and Brazil. According to a previous estimate 4,337 to 4,610 were expected to be infected [10]. However, these figures were based on official data on Latin American migrant populations and probably underestimate the true prevalence. Depending on the seroprevalence rates used for the estimations, we can expect that there were between 5,902 and 12,578 cases of Chagas disease in

\section{TABLE 4}

Nationalities of patients enrolled in screening programmes of pregnant women, blood donors and HIV-positive subjects, January 2008 to April $2010(\mathrm{n}=312)$

\begin{tabular}{|l|c|c|c|}
\hline Country & $\begin{array}{c}\text { Pregnant women } \\
n=214\end{array}$ & $\begin{array}{c}\text { Blood donors } \\
n=28\end{array}$ & $\begin{array}{c}\text { HIV-positive } \\
\text { subjects } \\
n=70\end{array}$ \\
\hline Argentina & $6(2.8 \%)$ & 0 & $9(12.9 \%)$ \\
\hline Bolivia & $7(3.3 \%)$ & 0 & 0 \\
\hline Brazil & $20(9.4 \%)$ & $8(28.5 \%)$ & $26(37.1 \%)$ \\
\hline Chile & $4(1.8 \%)$ & $4(14.3 \%)$ & $1(1.4 \%)$ \\
\hline Colombia & $7(3.3 \%)$ & $3(10.7 \%)$ & $3(4.3 \%)$ \\
\hline Costa Rica & $1(0.5 \%)$ & 0 & 0 \\
\hline Ecuador & $25(11.7 \%)$ & $1(3.6 \%)$ & $4(5.7 \%)$ \\
\hline El Salvador & $14(6.5 \%)$ & $1(3.6 \%)$ & 0 \\
\hline Honduras & $3(1.4 \%)$ & 0 & 0 \\
\hline Guatemala & 0 & 0 & 0 \\
\hline Mexico & $4(1.8 \%)$ & 0 & $2(2.9 \%)$ \\
\hline Nicaragua & $1(0.5 \%)$ & 0 & 0 \\
\hline Paraguay & $1(0.5 \%)$ & 0 & 0 \\
\hline Peru & $118(55.1 \%)$ & $5(17.9 \%)$ & $21(30 \%)$ \\
\hline Uruguay & $1(0.5 \%)$ & $1(3.6 \%)$ & $1(1.4 \%)$ \\
\hline Venezuela & $2(0.9 \%)$ & $3(10.7 \%)$ & $2(2.9 \%)$ \\
\hline Unknown & 0 & $2(7.1 \%)$ & $1(1.4 \%)$ \\
\hline
\end{tabular}

Italy in 2008 , in a Latin American population of up to 440,000 individuals (a number that includes undocumented migrants).

Few extensive evaluations of the Chagas disease infection rate in Latin American migrants in non-endemic countries have been published up to now, with the exception of Bolivians. For this reason, we used population prevalence rates in the countries of origin in 1990 [2] and 2005 [6]. The results were highly discordant. The more pessimistic scenario according to Schmunis et al. [2] prevalences would estimate about 12,000 Chagas disease cases in Italy in 2008.

Migrants from Bolivia are considered to be particularly at risk of Chagas disease [2, 11-14]. In the Lombardy Region alone, the Bolivian community counts about 20,000 people, most undocumented [15]. A majority of Latin American migrants in Italy are women [4], $65 \%$ in our study and similar to results from Spain and Switzerland [11, 12]. This aspect can contribute to a silent vertical diffusion of Chagas disease.

\section{Patients attending the two Centres}

In both Centres, activities of Chagas disease diagnosis, treatment and follow-up have rapidly grown in the last few years. For instance, only 28 serological tests were carried out at CTDN before 2005, and 548 thereafter. In patients attending the two Centres, an overall infection rate of $4.2 \%$ was found, higher than in other European countries, except Spain [12]. This result suffers from a selection bias because reference centres attract at-risk patients and promote the testing of relatives, and from an inhomogeneous population ( $18.4 \%$ were Bolivians).

\section{Migrants}

The infection detection rate among migrants (of whom $\mathbf{2 8 . 2} \%$ were Bolivians) was $\mathbf{1 1 . 3} \%$. Among Bolivians, $30.7 \%$ of individuals had a positive serological result, which is in accordance with other studies [11,12]. It has already been established [11] that Bolivian origin should be regarded as a predictive factor for $T$. cruzi infection.

The high prevalence of seropositive migrants raises the question of whether to screen all Latin Americans (excluding those originating from the Caribbean). Costeffectiveness studies are needed in this context, in order to better design public health interventions.

\section{Adopted children}

Data on seroprevalence of Chagas disease among adopted children in European countries are lacking. Dejour-Salamanca et al. estimate for France that 235 (between 165 and 384 depending on the prevalence used for calculation) of 19,389 adopted children might have had Chagas disease in the period from 1980 to 2007. Since 2004, less than 500 children have been adopted every year, therefore an extensive screening programme on adoptees could identify six cases per year [16]. 
In Italy, from the beginning of 2000 to the end of 2009 , 6,826 children were adopted from Latin American countries. They came mainly from: Colombia $(n=2,787$ adoptions), Brazil ( $n=2,265)$, Bolivia and Peru ( $n=475$ each), Chile $(n=409)$ and Guatemala $(n=114)$. The mean age of adoptees on arrival to Italy was 5,7 years [17]. Continent- or country-specific data on age were not available. Taking into account the infection prevalence of $7 \%$ detected in our sample of Bolivian adoptees, the PAHO estimation (8/100,000 annual incidence rate) for the other nationalities [6], and the mean age at adoption, we estimate 36 adopted children with Chagas disease in Italy at the end of 2009 (33 Bolivians and three with other backgrounds).

Only five cases have been diagnosed until now in adopted children, to our knowledge. The overall detection rate among all adoptees screened by our two centres was $0.9 \%$. Adopted children are a vulnerable population, at risk of stigmatisation. However, we believe that Chagas disease screening should be made available to all, considering the high efficacy of treatment at young age [18].

\section{Chagas disease and travellers}

Among 28 screened travellers, one had a positive serological result. This was a patient with acute food-borne Chagas disease after a short journey to Santa Catarina, Brazil in 2005, where 50,000 people had probably been exposed to contaminated sugar-cane juice [19]. Before our study, in 1997 a first acute case acquired in Brazil had been reported in Italy [3].

Sporadic cases of acute or chronic Chagas disease in travellers have been reported in France, Austria and Japan $[3,20]$. Chagas disease is potentially transmissible to travellers. Oral transmission, which can involve travellers, has been frequently recorded in recent years and is related to a more evident and severe form of the disease in the acute phase. Given that it is often asymptomatic in the early phase, the diagnosis may be easily missed. In case of chronic manifestation of the disease, the previous travel history may be overlooked.

Although international travel plays only an anecdotal role in imported Chagas disease, these cases can potentially be severe and misdiagnosed. Staff at travel clinics should be trained to consider Chagas disease prevention when giving travel advice as well as to recognise the early symptoms of acute Chagas disease when examining patients returning from Latin American countries.

\section{Screening programmes}

Chagas disease in pregnant women and newborns

In Europe, the prevalence of $T$. cruzi infection in Latin American women of child-bearing age varies from $3.4 \%$ to $9.7 \%[21,22]$. The lower prevalence in our series, also in comparison with the overall prevalence in migrants, is probably due to the low proportion of Bolivian nationals among the pregnant women we screened.
In Italy, there are no systematic screening programmes at national level, but ITDUF and Tuscany Region have started a specific programme, while the CTDN is currently testing all Latin American women presenting at their hospital for delivery or prenatal visit. This is an important issue, if we consider that in 2007 alone, 30 pregnant women were estimated to be infected in Italy and therefore might have given birth to two children with Chagas disease [3]. Moreover, it has recently been demonstrated in Spain that testing pregnant women for Chagas disease is cost-effective [23].

We did not identify any children who acquired Chagas disease from the mother. Nevertheless, maternal transmission is one of the most important factors to deal with in the control of the disease. The reported transmission rates from infected pregnant women to newborns vary from $1 \%$ to more than $10 \%$ in endemic countries [24] and from $2.7 \%$ to $7 \%$ in Europe [21,22]. In case a newborn is affected by Chagas disease, prompt treatment should be initiated. In Italy, no protocols for diagnosis and treatment of Chagas disease in newborns have been implemented so far.

\section{Chagas disease and transfusion of blood and blood} components or organ, cell and tissue transplantation In endemic countries, blood transfusion is probably the second most common way of dissemination of the disease [25]. Parasitaemia can persist for several years after infection [25], therefore a patient can transmit the disease several times. In non-endemic countries, transmission of Chagas disease by blood transfusion has been reported [3]. In Europe, Spain, France and the UK have specific policies for testing at-risk donors. There is still an open debate about the most cost-effective strategy for donor screening in non-endemic countries $[26,27]$.

Italy has not yet established a transfusional transmission prevention programme for Chagas disease; a questionnaire asks about prior diagnoses of tropical diseases (in case of Chagas disease the donor is permanently excluded) or travel to tropical countries (in that case, the donor is only temporarily excluded for three months and thereafter can donate blood without undergoing to any further screening for $T$. cruzi infection). With our limited survey we did not identify any infected donor. However, we think that new policies for donor screening are necessary in Italy. The issue of Chagas disease screening is presently being discussed at the National Blood Centre (personal communication, Giuliano Grazzini, 29 April 2011).

Chagas disease can also be transmitted through organ, cells or tissue donation [28]. In Italy, only patients who have already been diagnosed with Chagas disease are excluded from donation. It is common practice to seek a second opinion from by an infectious disease specialist in transplant medicine before organs are used from donors who are considered to be potentially infected with $T$. cruzi. At present, access to urgent diagnosis for 
T. cruzi infection is unavailable. In the forthcoming revision of the infectious disease prevention guidelines in transplant medicine, Chagas disease prevention will be discussed (personal communication, Paolo Grossi, 29 April 2011).

\section{Chagas disease and HIV Infection}

A further at-risk population, prone to severe manifestations of the disease, are HIV-positive persons. Chagas disease in HIV-positive patients has been predominantly described in those with advanced disease ( $\mathrm{CD}_{4}+$ $T$ cell counts below 200 cells $/ \mathrm{ml}$ ), and the infection was included in the group of AIDS-defining illness in Brazil and by PAHO [29].

In HIV-positive patients, the most relevant clinical manifestations of Chagas disease result from reactivation of a chronic T. cruzi infection [30]. The central nervous system is the most commonly affected site, in approximately $75 \%$ of cases, with clinical signs of acute meningoencephalitis or space-occupying lesions, rapid clinical progression and a high fatality rate of $79 \%[30,31]$ The heart is the second most commonly affected organ (25\% to $44 \%$ of cases) [31,32]. Peripheral blood parasitaemia, and also cerebrospinal fluid invasion, are very common in those subjects [32].

The treatment of reactivated Chagas disease is based on the standard drugs benznidazole or nifurtimox. However, the duration of therapy has not been established in HIV/AIDS patients; longer courses of treatment followed by secondary prophylaxis (at least until immune reconstitution has been achieved) [33] or chronic suppressive therapy are likely to be required [31]. Spanish guidelines recommend treatment of Chagas disease in HIV-positive patients with positive PCR for T. cruzi in the blood [33]. Some experts suggest primary prophylaxis for infected individuals with a CD4+ T cell count lower than 200 cells per $\mu \mathrm{L}$ [31].

Many cases have been reported of Chagas disease reactivation in HIV-positive patients, most of them from Latin America [31], while data from Europe are very limited. To our knowledge, only one case of a meningoencephalitis in a 35 year-old Argentinian man living in Spain, has been published and only two serological screening programmes have been carried out, both in Spain, in HIV-positive people of Latin America origin, finding prevalences of $T$. cruzi infection between $2 \%$ and $10.5 \%[34,35]$.

Although we did not identify any case of Chagas disease in the HIV-positive population screened, we found a high proportion of patients with a history of low $\mathrm{CD}_{4}+$ $\mathrm{T}$ cell counts under $200 / \mathrm{ml}$, which deserves consideration. We believe that all HIV-positive patients with epidemiological risk should be tested for Chagas disease as stated in the Brazilian guidelines [36].

\section{Conclusions}

The present study on Chagas disease epidemiology is the first ever conducted in Italy. Together with previous estimations [10], it outlines a worrisome scenario, although the picture is still largely incomplete. Chagas disease can be considered an emerging problem in Italy. We believe that our country should urgently improve the access to diagnosis and treatment and implement an efficient approach to case finding and transmission control. A network of Centres working on Chagas disease should be set up to stimulate research, inform and educate both healthcare providers and the public, and offer a qualified service for disease management.

\section{Acknowledgments}

This work has been supported by the European Community within the 7 th Framework Programme, under the COHEMI project (COordinating resources to assess and improve HEalth status of Mlgrants from Latin America) grant agreement No. FP7-GA-261495.

The authors wish to thank Dr. C. Fedrigo, Blood Centre, Hospital Sacro Cuore, Negrar for his contribute in blood donor screening and all the nurses and obstetrics of CTDN and ITDUF who gave their voluntary collaboration in realising the screenings and who put all their efforts in following patients with humanity and professionality.

\section{References}

1. Hotez PJ, Bottazzi ME, Franco-Paredes C, Ault SK, Periago MR. The Neglected Tropical Diseases of Latin America and the Caribbean: A Review of Disease Burden and Distribution and a Roadmap for Control and Elimination. PLoS Neglected Tropical Diseases. 2008;2(9):e300.

2. Schmunis GA, Yadon ZE. Chagas disease: a Latin American health problem becoming a world health problem. Acta Trop. 2010;115(1-2):14-21.

3. World Health Organization (WHO). Control and prevention of Chagas disease in Europe. Report of a WHO Informal Consultation (jointly organized by WHO headquarters and the WHO Regional Office for Europe) Geneva, Switzerland, 17-18 December 2009. Geneva: WHO; 2010. Report No: WHO/HTM/NTD/IDM/2010.1 Available from: http://www. fac.org.ar/1/comites/chagas/Chagas_WHO_Technical\%20 Report_16_06_10.pdf

4. Caritas/Migrantes. Immigrazione dossier statistico 2009. XIX Rapporto. [Immigration Statistical Dossier 2009. XIXthReport]. Rome: Caritas Italiana; 2009. Italian. Available from: http:// www.caritasitaliana.it/materiali/Pubblicazioni/libri_2009/ dossier_immigrazione2009/scheda.pdf

5. Angheben A, Bartoloni A, Anselmi M, Gradoni L, Bottieau E, Carlier Y et al. Trypanosoma cruzi infection (Chagas disease) in Europe. Conclusions of the 6th European Congress of Tropical Medicine and International Health; Sep 6-10; Verona, Italy. Bull Soc Pathol Exot. 2010;103:359-63.

6. Panamerican Health Organization (PAHO). Estimacion cuantitativa de la enfermedad de Chagas en las Americas. [Quantitative estimate of Chagas disease in the Americas]. Report no: OPS/HDM/CD/ 425-06:6). Washington: PAHO; 2006. Spanish. Available from: http://www.bvsops.org.uy/pdf/ chagas19.pdf

7. Istituto Italiano di Statistica (ISTAT). Demo ISTAT. [Accessed 4 Jan 2010]. Available from: http://demo.istat.it/

8. World Health Organization (WHO). WHO Expert Committee on the Control of Chagas Disease (2000: Brasilia, Brazil). Control of Chagas disease: second report of the WHO expert committee. Report No: WHO Technical Report Series 905 , 1-109. Geneva: WHO; 2002. Available from: http://whqlibdoc. who.int/trs/WHO_TRS_905.pdf

9. Schijman AG, Bisio M, Orellana L, Sued M, Duffy T, Mejia Jaramillo $A M$, et al. International study to evaluate PCR methods for detection of Trypanosoma cruzi DNA in blood samples from Chagas disease patients. PLoS Negl Trop Dis. 2011;5(1):e931. 
10. Guerri-Guttenberg RA, Ciannameo A, Di Girolamo C, Milei JJ. Mal di Chagas: un problema emergente di salute pubblica in Italia? [Chagas disease: an emerging public health problem in Italy?]. Infez Med. 2009;17(1):5-13. Italian.

11. Jackson Y, Gétaz L, Wolff H, Holst M, Mauris A, Tardin A et al. Prevalence, clinical staging and risk for blood-borne transmission of Chagas disease among Latin American migrants in Geneva, Switzerland. PLoS Negl Trop Dis. 2010;4(2):e592.

12. Muñoz, i Prat JG, Gallego M, Gimeno F, Treviño B, LopezChejade $\mathrm{P}$ et al. Clinical profile of Trypanosoma cruzi infection in a non-endemic setting: Immigration and Chagas disease in Barcelona (Spain). Acta Trop. 2009;111(1):51-5.

13. Pérez-Ayala A, Pérez-Molina JA, Norman F, Navarro MF, MongeMaillo B, Diaz-Menéndez $M$ et al. Chagas disease in Latin American migrants: a Spanish challenge. Clin Microbiol Infect. 2011;17(7):1108-13.

14. Gascón J, Bern C, Piñazo MJ. Chagas disease in Spain, the United States and other non-endemic countries. Acta Trop. 2010;115(1-2):22-7.

15. Ghiringhelli B, Marelli S, editors. Accogliere gli immigrati, Testimonianze di inclusione socio-economica. [Welcoming the immigrants, Testimonies of socio-economic inclusion]. Rome: Carocci;2009. Italian.

16. Salamanca DD, La Ruche G, Tarantola A, Degail M, Jeannel D, Gastellu-Etchegorry M. [Chagas disease in France: estimated number of infected persons and cardiac diseases in 2009, by risk groups]. Bull Soc Pathol Exot. 2009;102:285-90. French.

17. Presidenza del Consiglio dei Ministri. Commissione per le Adozioni Internazionali. Dati e prospettive nelle adozioni internazionali; rapporto sui fascicoli dal 1 gennaio al 31 dicembre 2009. [Commission for International Adoptions. Data and prospects in international adoptions; report on cases from 1 January to 31 December 2009]. Rome: ANOLF; 2010. Italian. Available from: http://www.anolf.it/archivio/download/ rapporto_pcm_2009.pdf

18. Bern C, Montgomery SP, Herwaldt BL, Rassi Jr A, Marin-Neto JA, Dantas RO et al. Evaluation and treatment of chagas disease in the United States: a systematic review. JAMA. 2007;298(18):2171-81.

19. ProMED-mail. Trypanosomiasis, foodborne - Brazil (Santa Catarina) (02). Archive number 20050325.0870. 25 March 2005

20. Takeno M, Seto S, Kawahara F, Yamachika S, Yano K, Tsuda N. Chronic Chagas' heart disease in a Japanese-Brazilian traveler. A case report. Jpn Heart J. 1999;40(3):375-82.

21. Orti Lucas RM, Parada Barba MC. Prevalencia de Trypanosomiasis americana en mujeres de un area de salud, Valencia, 2005-2007. [Prevalence of american trypanosomiasis in pregnant women from a health area of Valencia, Spain: 2005-2007]. Rev Esp Salud Publica. 2009;83(4):543-55. Spanish.

22. Muñoz J, Oriol C, Juncosa T, Vergé $M$, del Pino M, Fumado V et al. Prevalence and Vertical Transmission of Trypanosoma cruzi Infection among Pregnant Latin American Women Attending 2 Maternity Clinics in Barcelona, Spain. Clin Infect Dis. 2009;48(12):1736-40.

23. Sicuri E, Muñoz J, Piñazo MJ, Posada E, Sanchez J, Alonso PL et al. Economic evaluation of Chagas disease screening of pregnant Latin American women and of their infants in a non endemic area. Acta Trop. 2011;118(2):110-7.

24. Torrico F, Alonso-Vega C, Suarez E, Rodriguez P, Torrico MC, Dramaix $M$ et al. Maternal Trypanosoma cruzi infection, pregnancy outcome, morbidity, and mortality of congenitally infected and non-infected newborns in Bolivia. Am J Trop Med Hyg. 2004;70(2):201-9.

25. Castro E. Chagas' disease: lessons from routine donation testing. Transfus Med. 2009;19(1):16-23.

26. Assal A, Corbi C. [Chagas disease and blood transfusion: an emerging issue in non-endemic countries]. Transfus Clin Biol. 2011;18(2):286-91. French.

27. Perkins HA, Busch P. Transfusion-associated infections: 50 years of relentless challenges and remarkable progress. Transfusion. 2010;50(10):2080-99.

28. Rassi A, Jr, Rassi A, Marin-Neto JA. Chagas disease. Lancet. 2010;375(9723):1388-402.

29. Panamerican Health Organization (PAHO). Definición de la OMS de caso de infección por el VIH a efectos de vigilancia y revisión de la estadificación clínica y de la clasificación inmunológica de la enfermedad relacionada con el VIH en adultos y niños. [WHO definition of cases of infection with HIV for surveillance purposes and review of the clinical staging and immunological classification of HIV-related disease in adults and children.]. Report no: OPS/FCH/HI/04-09.E. Washington: PAHO;2009. Spanish. Available from: http://new.paho.org/hq/ dmdocuments/2009/DEFINICION_ESTADIFICACION2.pdf
30. Diazgranados CA, Saavedra-Trujillo $\mathrm{CH}$, Mantilla M, Valderrama SL, Alquichire C, Franco-Paredes C. Chagasic encephalitis in HIV patients: common presentation of an evolving epidemiological and clinical association. Lancet Infect Dis. 2009;9(5):324-30.

31. Ferreira MS, Nishioka SD, Silvestre MT, Borges AS, NunesAraujo FR, Rocha A. Reactivation of Chagas' disease in patients with AIDS: Report of three new cases and review of the literature. Clin Infect Dis. 1997;25(6):1397-400.

32. Verdu J, De Paz F, Castano V, Torrus D, Reus S. Reactivation of Chagas disease with central nervous system involvement: peripheral blood smear evidence. Int J Infect Dis. 2009;13(6):e527-8.

33. Panel de expertos de GESIDA y Plan Nacional sobre el Sida. [GESIDA Expert Panel and National AIDS Plan]. Tratamiento de las infecciones oportunistas en pacientes adultos y adolescentes infectados por el virus de la inmunodeficiencia humana en la era del tratamiento antirretroviral de gran actividad. Recomendaciones del Grupo de Estudio del Sida (GESIDA)/Plan Nacional sobre el Sida. [Treatment of Opportunistic Infections in Adolescent and Adult Patients Infected by the Human Immunodeficiency Virus During the Era of Highly Active Antiretroviral Therapy. Guidelines of the AIDS Study Group (GESIDA)/National AIDS Plan]. Enferm Infecc Microbiol Clin. 2008;26(6):356-79. Spanish.

34. Llenas-Garcia J, Hernando A, Fiorante S, Salto E, Rodriguez V, Matarranz M. Evaluacion de un programa de cribado de enfermedad de Chagas en una Unidad VIH en Madrid. Madrid. [Evaluation of a screening program for Chagas disease in an HIV unit in Madrid]. Presentation in: VI Taller sobre enfermedad de Chagas Importada: Inmunosupresion y Trasplantes. [Workshop on Imported Chagas disease: Immunosuppression and Transplantation]. Enfermedades Emergentes. 2010;12(Suppl 1):29-32. Spanish.

35. Rodriguez-Guardado A, Asensi Alvarez V, Rodriguez Perez M, Mejuto Alvarez P, Flores-Chavez M, Alonso Gonzalez P, et al. Screening for Chagas' disease in HIV-positive immigrants from endemic areas. Epidemiol Infect. 2011;139(4):539-43.

36. Recommendations for diagnosis, treatment and follow-up of the Trypanosoma cruzi: human immunodeficiency virus co-infection. Rev Soc Bras Med Trop. 2006;39:392-415. Portuguese 